\title{
Evaluating the Effectiveness of Distance Learning in Higher Education during COVID-19 Global Crisis: UAE Educators' Perspectives
}

\author{
Jamal N. Al-Karaki \\ Abu Dhabi Polytechnic University, Abu Dhabi, UAE \\ The Hashemite University, Zarqa, Jordan \\ ORCID: 0000-0001-5408-5087 \\ Nedal Ababneh \\ Abu Dhabi Polytechnic University, Abu Dhabi, UAE \\ ORCID: 0000-0002-5051-4638 \\ Yasir Hamid \\ Abu Dhabi Polytechnic University, Abu Dhabi, UAE \\ ORCID: 0000-0003-1334-2651 \\ Amjad Gawanmeh \\ University of Dubai, Dubai, UAE \\ Concordia University, Canada \\ ORCID: 0000-0002-3897-0681
}

\begin{abstract}
The COVID-19 Pandemic affected all sectors worldwide including education sector changing the students learning environment at a large scale. In the education sector, governments had to close schools and universities around the world and turn into online mode of delivery. The sudden transformation to online learning demands educators and institutions to develop more innovative teaching methods in supporting students during this growing crisis. It is pertinent that this is the era of large-scale online learning, where education is delivered remotely utilizing various digital platforms. To this end, this move presented many challenges to students, educators, families, administrators, and government regulations. In this paper, we conduct an oriented and well-rounded survey that captures all aspects of distance learning verticals as perceived by educators in order to study online delivery aspects, including teaching models, communication media, and teaching best practices in distance learning. The paper will answer subtle and comprehensive questions related to student satisfaction and success, technical needs and challenges, teaching models, educator mobility, etc. across different universities in the UAE. In particular, the paper tries to identify best model to use given many key issues related to the adoption of e-learning during COVID-19. Overall, the survey results showed almost all participants agreed that online learning during the COVID-19 is a very good alternative solution to Face-to-Face approach. However, teaching models do vary in promoting students' participation and students' engagement. All participants agree that absence of the proper infrastructure at home will hinder the operation especially in courses with hands-on components. Finally, the educators questioned the credibility of online assessments despite the enforced exam integrity tools and methods. The paper concluded with many recommendations for continuous development of the distance learning systems during and after COVID -19.
\end{abstract}

Keywords: COVID-19, distance learning, online education, technology adoption, education models, higher education 


\section{INTRODUCTION}

The sudden 2019 novel coronavirus (COVID-19) pandemic resulted in several immediate lockdowns all over the world on all aspects including education (Umoh et al., 2020). Most countries enforced common rules to contain the spread of COVID-19 through social distancing and using face masks or even complete lockdown. As such, many governments were enforced to shutdown teaching institutions as a necessary precaution measure to restrict the spread of pandemic (Viner et al., 2020). The COVID-19 was first identified in Wuhan, China, which can infect any person irrespective of their age but older people and those with existing health conditions such as diabetes, heart disease, cardiovascular disease, immune suppression, etc., are more vulnerable to contract the virus than any other group of individuals. In addition, there seem to be sex differences in mortality and vulnerability to the disease (China CDC, 2020).

The sudden transformation to online learning has changed completely the shape of normal teaching practice demanding educators and institutions to develop more innovative teaching methods in supporting students during this growing crisis. Due to the exceptional situation generated by the COVID-19 crisis, the impact on education systems and its elements including schools, universities, educators and students, became a subject of great interest for many researchers worldwide. The research efforts on best and effective teaching practices and outcomes have been a rich field (Iyer, Aziz, \& Ojcius, 2020). As the pandemic continues and its variations spread around the world, more data shall be collected on the effect of continual institutions shutdown on the learning practices.

In general, online learning was always considered an alternative or complement to traditional learning. However, such form of education has become a crucial element for maintaining the activity of schools and universities during COVID-19 worldwide. Online learning has various advantages such as low cost, following the latest developments, freedom of choosing the needed teaching materials, can be accessed from anywhere and anytime and it is universal (Hamid et al., 2020). Although there are many solutions available for online learning, integrity of online assessments might be the most challenging part in online learning. In fact, many universities were concerned about how to evaluate and assess students' learning objectives with integrity and fairness (Hamid et al., 2020).

The United Arab Emirates (UAE) enforced the online learning mode across the whole educational system starting March 2020. The resolution impacted both public and private schools as well as higher education institutions. Higher education institutions in the UAE are advised by the MoE to replace face to face learning with online learning until the end of the academic year 2019-2020 (MoE.gov.ae, 2020). The Ministry of Education (MoE) circulated rules and regulations, to be used as guidelines for the whole universities in the UAE addressing all the issues and inquiries raised by the universities including rules to conduct online assessments. In addition, the teachers' perspectives have a great impact on the teaching methodology process. The successful implementation of online learning tools and methods will be influenced by the same aspects related to educator's perspectives on technology integration in the classroom and the teaching method practiced in that classroom.

In UAE, Synchronous and real time delivery of classes were conducted mainly over Blackboard Collaborate Ultra (part of Blackboard LMS), while some others used Microsoft Teams when necessary for all online activities. Learning Management System (e.g., Blackboard) were also used for online exams, homework, quizzes, etc. This sudden conversion was devastating to everyone and required all to learn technology features in short time and were a stressful situation to adapt to. Many people questioned the assessment integrity. Many institutions required the use of exam integrity tools (e.g., LockDown Browser) and exam proctoring tools (e.g., Respondus Monitor). It is worth mentioning that UAE has invested heavily in the communication and IT infrastructure for stable internet connection in order to minimize technical issues related to online teaching and learning. Towards this end, the shift of classes from classical classroom environment to virtual ones adopting the relevant technology applications warrants more dedicated studies and take into consideration the perspectives of all stakeholders such as educators, students, administrators, families, and decision makers. 
The main objective of this paper is to study and report on the perspectives' on the online learning experience during the COVID-19 pandemic in order to provide recommendations for enhancing the online learning system in UAE. The study starts by examining how the process of learning and education were affected during current times of COVID-19 crisis. Then, a thorough investigation of educator's perspective on the use of various technology platforms and their impact on information and program delivery. The analysis include both main opportunities and difficulties that educators come across while learning online. As such, the paper provides recommendations on best methods to deliver courses and how content of the course can be mapped to accommodate the challenges imposed by the new methods of education due to COVID-19 crisis.

\section{RELATED WORK}

The COVID-19 pandemic has global impact on human life, particularly health, transportation and education. According to Telli, Yamamoto, and Altun (2020), education is the sector most affected by COVID-19 after the health sector. Literature provides results in favor of using online learning in higher education in terms of its usefulness, effectiveness, and positive influence on student's performance given the proliferation of modern communication technologies. Online learning can run well with the existence of information technology that has been developing quickly with number of applications such as google class, WhatsApp, zoom, and other information media and internet networks that can connect lecturers and students (Viner et al., 2020) reported that while the closure of universities was a necessary precaution measure to stop the spread of COVID-19, the sudden reliance on online learning required unprecedented efforts and teaching practices innovative learning and teaching methods in order to support students during the crisis. Furthermore, the teaching methodologies used in online education should stimulate learning in students while the course design shall support their individual needs (Huang et al., 2020).

Recently, the work in (Malkawi et al., 2021) complements our study by considering some aspects of school teachers' perspective towards e-learning across the UAE. Several other studies were conducted to identify challenges during this unprecedented situation (e.g., Basilaia \& Kvavadze, 2020; Demuyakor, 2020; GarcíaMorales et al., 2021; Mailizar et al., 2020; Sintema, 2020; Zhou et al., 2020).

Tzivinikou et al. (2020) evaluated the psychometric properties of the Distance Education Attitudes Scale (DEAS) by asking educators to fill out the domains of socio-demographic data forms. Results showed that no significant differences were observed between these two Domains. It was concluded that teachers' attitudes towards efficacy in distance education and difficulties related to distance education are considered as significant factors for the implementation of distance education during COVID-19 crisis.

Coman et al. (2020) considered how Romanian universities managed to provide knowledge during the Coronavirus pandemic using exclusive online teaching and learning where students' perception regarding online learning and E-learning platforms. As previous studies showed that online based education systems have many benefits for students as they are exposed to several complementary tools (Coman et al., 2020). In addition, several studies that we discussed above showed that many students favor online learning, hence this study was necessary to understand the perspective of educators at the other side.

Lokanath et al. (2020) presented a case study in India of one university adaptation of teaching-learning during COVID-19 crisis. The research focused on the use of existing resources in educational institutions to effectively transform face-to-face education into online education by utilizing virtual classes and online tools.

Muthuprasad et al. (2021) conducted a survey to study the Agricultural Student's perception and preference towards the online learning. Authors studied the student's preferences for various attributes of online classes. This study focused on how students perceive online learning, and which format they prefer. There was no inclusion of the pinion of instructors. In another work (Paudel, 2021) surveyed the point of view of both teachers and students on the benefits and challenges of online education amid COVID-19 in Nepal. The study identified several benefits of the situation such as promoting online research, connecting participants to the community worldwide and having more freedom. 
Baticulon et al. (2021) performed a study to identify barriers to online learning from the perspective of medical students in the Philippines. The study is important as it targets one of the developing country, and takes the perspective of students. García-Peñalvo (2021) conducted a similar study to identify areas of strength and weaknesses in universities in Spain during the pandemic. Mittal et al. (2021) presented a theoretical model based on a time-series to analyze several factors about of the adoption of online teaching at the time of the outbreak of COVID-19. Kundu and Bej (2021) studied the Indian students' perception of being ready for the sudden shift to online education. Authors also reported guidelines for institutional governance to respond to such situation. This study is very much related to ours from the point that it addressed consequences of the sudden shift, however, this one was applied on students, while ours will be applied on instructors.

\section{THE RESEARCH OBJECTIVES/QUESTIONS}

This study aims to examine the effect of online learning on student's engagement in UAE main universities from educator's perspectives during COVID-19. Furthermore, it addresses the impact of technology adoption on online learning, and discuss the challenges encountered by the educators during COVID-19.

The study focuses on educators' perspectives to find solid answers for several key research questions/objectives as listed below:

1. To disclose the popular online tools and E-learning digital platforms that are currently used for online learning in UAE adopted during COVID-19 crisis.

2. To study the perceptions of educators on the effectiveness of online education during COVID-19 crisis in UAE.

3. To examine the challenges faced by the educators in adapting to the online education requirements in UAE imposed by COVID-19 crisis (e.g., limited mobility, online assessment, student behavior, etc.).

4. To examine how the student engagement was affected by online learning during COVID-19 crisis from educators perspective in UAE.

\section{MATERIALS AND RESEARCH METHODOLOGY}

In this section, we describe the research methodology including research design, tools, and administration details of the study. The study used both quantitative and qualitative methodologies to study the perceptions of educators with respect to adoption of online learning process during the lockdown period. This study is de-limited to UAE Universities in major emirates like Abu Dhabi. The research employed the descriptive survey design using the quantitative research approach. The online questionnaire was sent out to educators in different higher education institutions across the UAE. The responses were collected over a period of two weeks. Adopting an online tool was a very effective option to reach the educators as face-to-face contact was not an option during the pandemic. The Likert scale used to measure the descriptive survey where five Likert scale were used ranging from Strongly Agree (SA), Agree (A), Neutral (N), Disagree (D) to Strongly Disagree (SD).

Research Design: This research is mainly based on collecting people beliefs, opinions, attitudes, motivation, and behavior through a survey design. A detailed survey was designed and adopted in the study as an appropriate tool to generate the vital facts of the people under study.

Data Collection Method: The study was conducted online and data was collected online by inviting educators to fill the online questionnaire, irrespective of the geographical location. The questionnaire was by email and was made available through the application SurveyMonkey during the spring term of academic year 20192020. The research received the approval of Ministry of education of UAE. The participants in the study were briefed about the purpose of the survey at the beginning and related consent. Responses were collected over a period of one month. 
Table 1. Analysis of information about respondents: gender, age, and location in UAE

\begin{tabular}{|c|c|c|c|c|c|c|c|c|}
\hline Gender D & & & Age Distribution & & & Location/Emirate & & \\
\hline Variable & $\mathrm{F}$ & $\mathrm{P}$ & Variable & $\mathrm{F}$ & $\mathrm{P}$ & Variable & $\mathrm{F}$ & $\mathrm{P}$ \\
\hline Male & 24 & $26.67 \%$ & $18-24$ & 0 & $0.00 \%$ & Abu Dhabi & 84 & $94.38 \%$ \\
\hline \multirow[t]{5}{*}{ Female } & 66 & $73.33 \%$ & $25-34$ & 23 & $25.84 \%$ & Ajman & 2 & $2.25 \%$ \\
\hline & & & $35-44$ & 29 & $32.58 \%$ & Dubai & 2 & $2.25 \%$ \\
\hline & & & $45-54$ & 18 & $20.22 \%$ & Sharjah & 2 & $2.2 \%$ \\
\hline & & & $55-64$ & 17 & $19.10 \%$ & & & \\
\hline & & & $65+$ & 2 & $2.25 \%$ & & & \\
\hline Total & 90 & 100 & Total & 90 & 100 & Total & 90 & 100 \\
\hline
\end{tabular}

Table 2. Analysis of metrics about employment information for respondents

\begin{tabular}{|c|c|c|c|c|c|c|c|c|}
\hline \multicolumn{3}{|c|}{ Educational Qualification } & \multicolumn{3}{|l|}{ Monthly Income } & \multicolumn{3}{|l|}{ Employment Sector } \\
\hline Variable & $\mathrm{F}$ & $\mathrm{P}$ & Variable & $\mathrm{F}$ & $\mathrm{P}$ & Variable & $\mathrm{F}$ & $P$ \\
\hline Diploma & 2 & $2.25 \%$ & Less than 5,000 & 1 & $1.12 \%$ & Governmental & 86 & $95.56 \%$ \\
\hline Bachelor's degree & 15 & $16.85 \%$ & $5,000-9,999$ & 0 & $0.00 \%$ & Private & 2 & $2.22 \%$ \\
\hline Higher Diploma & 1 & $1.12 \%$ & $10,000-19,999$ & 32 & $35.96 \%$ & $\begin{array}{l}\text { International bodies } \\
\text { and organizations }\end{array}$ & 0 & $0.00 \%$ \\
\hline M.A & 37 & $41.57 \%$ & $20,000-39,000$ & 54 & $59.55 \%$ & $\begin{array}{l}\text { Management and } \\
\text { consultations }\end{array}$ & 1 & $1.11 \%$ \\
\hline PhD & 35 & $38.20 \%$ & More than 40,000 & 3 & $3.37 \%$ & Other & 4 & $4.49 \%$ \\
\hline Total & 90 & 100 & Total & 90 & 100 & Total & 90 & 100 \\
\hline
\end{tabular}

Population and Sample: Educators with titles of professor, associate professor, assistant professor, and lecturer from targeted universities are selected as sample for the quantitative study using disproportional sampling. There was a focus on top five universities educators that converted to online delivery mode early during the pandemic. The focus was on the most important five universities in UAE that exist in the emirate of Abu Dhabi for the present research. These may only account for $40 \%$ of all institutions in UAE, but they account for $60 \%$ of number of teaching faculty in whole UAE. All the sample respondents provided full cooperation in responding to all parts of the questionnaire. Faculty peer interviewing provided valuable feedback and suggestions that were reflected in the recommendations part of this study. Descriptive statistics were used for quantitative data analysis. The study was passed in the ethical committee of the University.

All the respondent educators are full time teaching faculty in their respective institutions. The researchers used a purposive sampling technique to select highly representative 100 respondents. The population of the study comprised the faculty members (professors, lecturers, etc.) in governmental institutions involved in online learning in UAE during COVID-19 lock down, which is estimated to be around 450 faculty. Around 100 participants, mainly from Abu Dhabi emirate, representing approximately $20 \%$ of targeted population responded to the online survey within three weeks timeframe. The majority of respondents are female, comprising of $73 \%$ of overall respondents. In addition, there were 10 educators ( 5 male and 5 female) selected for semi-structured interviews to collect qualitative data concerning their perceptions towards the online learning process. Table 1 shows the analysis of information about respondents including gender, age, designation, and location.

In Table 1, location distribution shows that 84 of the respondents representing 94.38 are currently based in Abu Dhabi, followed by 2 respondents representing 2.25\% based in Ajman, 2 respondents representing 2.25 based in Dubai, while 2 respondents representing 2.2\% based in Sharjah. Table 2 shows analysis of metrics about employment information for respondents, the income of participants and the employment sector distribution of respondents.

Table 3 shows the Analysis of information about courses and classes distribution of respondents. The second part of the table shows the analyses of the number of classes taught by a teacher. Class size is shown in the last part of the table. In summary, most respondents were undergraduate programs instructors, with medium size classes. Size of the class was distributed among all categories with no dominant number. 
Al-Karaki et al. / Contemporary Educational Technology, 2021, 13(3), ep311

Table 3. Analysis of Information about Courses and Classes Distribution of Respondents

\begin{tabular}{lcclcclcc}
\hline Course Level & \multicolumn{3}{l}{ Number of classes taught } & \multicolumn{2}{l}{ Class Size } \\
\hline Variable & $\mathrm{F}$ & $\mathrm{P}$ & Variable & $\mathrm{F}$ & $\mathrm{P}$ & Variable & $\mathrm{F}$ & $\mathrm{P}$ \\
\hline Undergraduate & 68 & $75.56 \%$ & 1 & 3 & $3.33 \%$ & Less than 10 & 10 & $11.11 \%$ \\
Graduate & 3 & $3.33 \%$ & 2 & 5 & $5.56 \%$ & $10-25$ & 65 & $72.22 \%$ \\
Under and grad & 15 & $16.67 \%$ & 3 & 16 & $17.78 \%$ & $26-40$ & 22 & $24.44 \%$ \\
public / training & 1 & $1.11 \%$ & 4 & 24 & $26.67 \%$ & $41-50$ & 4 & $4.44 \%$ \\
Other & 3 & $3.33 \%$ & 5 & 12 & $13.33 \%$ & $51-100$ & 1 & $1.11 \%$ \\
& & & 6 or more & 30 & $33.33 \%$ & More than 100 & 0 & $0.00 \%$ \\
\hline Total & 90 & 100 & Total & 90 & 100 & Total & 90 & 100 \\
\hline
\end{tabular}

The Research Instrumentation: A non-standardized research instrument (questionnaire) was used for data collection. The questionnaire was titled "evaluating the effectiveness of online learning in higher education during COVID-19 global crisis in UAE". The questionnaire included items corresponding to the four research questions/objectives using Likert scale of 5 levels (Likert scale $5=$ Strongly Agree, $1=$ Strongly Disagree). It also contains a number of socio-demographic variables (e.g., gender, degree level, field of study) that was used for descriptive analysis.

Reliability of the Instrument: Pearson Product Moment Correlation was used for this purpose by providing the instrument into two groups that were not part of the study obtaining a ratio between 0.75 and 0.95 , which showed that the instruments were highly reliable.

Administration of Instrument: The instrument was administered through online survey and follow-up communication emails by the researchers to the respondents via the institute authority. This method was adopted given the compliance of social and physical distancing. The respondents were given two weeks to complete the questionnaire before they were collected for analysis.

Method of Data Analysis: Data collected were processed using the Statistical Package for Social Science (SPSS) and MS Excel. The questionnaire was designed to be answered using descriptive statistics with an extra hypothesis that was evaluated using the Pearson Product-Moment Correlation (PPMC) analysis at the strength of a linear association between variables $r=0.5$, and where all variables are treated equally.

\section{FINDINGS}

In this section, we present research question/objective wise findings as a result of percentage analysis and content analysis of the collected online survey data where all responses were considered in the analysis. In addition, feedback collected directly from some educators in authors institute were included in the analysis section.

\section{Findings Related to Research Question/Objective One}

In this subsection, the survey data discloses the popular online tools and E-learning digital platform that are currently used for online learning in UAE during COVID-19 crisis. Table 4 provides responses for the resources used for distance learning. Many participants stated that they use LMS provided by their institute, and the majority stated that they use collaboration platforms that support live-video communication. The participant was asked about the type of internet service they have, where 5 respondents representing $5.33 \%$ stated that they use Wired Broadband Access Ethernet or Fiber optic as their internet service. In addition, 77 respondents representing 85.56\% stated that they use Wireless Broadband Access - Wi-Fi. 5 respondents representing 5.33\% stated that they use Mobile broadband (e.g., 4G, 5G). Finally, 3.33\% stated that they use other methods of internet service (e.g., satellite). In addition, 86 respondents representing opted yes that they have the infrastructure in place to easily communicate with students, while 3 respondents representing $3.37 \%$ opted otherwise. Among the variety of digital modes of online learning, almost all the educators were using collaboration platforms that support live-video communication (e.g., Microsoft Teams, Zoom, Skype, Hangouts Meet), while WhatsApp/Telegram and Email were used for educational interactions for clarification of doubts and answering quick queries. 
Table 4. What online tools/resources are you using for distance learning? Select all that apply

\begin{tabular}{lcc}
\hline Variable (online tools/resources used) & Frequencies & Percentage \\
\hline Digital learning management systems (e.g., BBLearn, Edmodo, Google Classroom, Moodle, & 44 & $48.89 \%$ \\
Seesaw) & 0 & $0.00 \%$ \\
A system with strong offline functionality (e.g., Kolibri, Rumie, Ustad Mobile) & 0 & $0.00 \%$ \\
Massive Open Online Course (MOOC) platforms (e.g., Alison, Canvas network, EdX) & 22 & $24.44 \%$ \\
Self-directed learning content (e.g., Youtube, Code.org, Khan Academy, Quizlet) & 78 \\
Collaboration platforms that support live-video communication (e.g., Microsoft Teams, Zoom, & $86.67 \%$ \\
Skype, Hangouts Meet) & 14 & $15.56 \%$ \\
Instant messaging system (like WhatsApp, Telegram, etc.) & 18 & $10.22 \%$ \\
Other (please specify) & 176 \\
\hline Total Responses & & \\
\hline
\end{tabular}

Table 5. Advantages of using the online learning system during COVID-19 crisis, and availability of technology and communication methods

\begin{tabular}{|c|c|c|c|c|c|}
\hline Variable & SD & $\mathrm{D}$ & $\mathrm{N}$ & A & SA \\
\hline The online learning system is useful to the education process in my institute & 6 & 3 & 19 & 51 & 12 \\
\hline $\begin{array}{l}\text { The online learning system helps in the continuation and sustainability of work in my } \\
\text { institute }\end{array}$ & 4 & 5 & 14 & 47 & 21 \\
\hline $\begin{array}{l}\text { The online learning system helps in reducing costs associated with the operation of my } \\
\text { institute }\end{array}$ & 3 & 10 & 20 & 44 & 13 \\
\hline The online learning system helps in the progress of the education process in my institute. & 7 & 8 & 26 & 36 & 13 \\
\hline Total & 20 & 26 & 79 & 178 & 59 \\
\hline $\begin{array}{l}\text { The institute provides internet service for me in my remote working location to enable me to } \\
\text { complete my tasks during the COVID-19 crisis. }\end{array}$ & 33 & 34 & 11 & 9 & 2 \\
\hline $\begin{array}{l}\text { My internet service is available in my new work environment without any interruption during } \\
\text { the crisis. }\end{array}$ & 3 & 14 & 19 & 36 & 16 \\
\hline $\begin{array}{l}\text { The quality of the available internet service during the crisis is compatible with systems and } \\
\text { requirements for conducting online learning and complete my work duties. }\end{array}$ & 5 & 10 & 22 & 35 & 17 \\
\hline Experience frequent problem with the technology setup for the distance learning. & 6 & 34 & 25 & 17 & 6 \\
\hline Total & 47 & 92 & 77 & 97 & 41 \\
\hline
\end{tabular}

Table 6. The degree of complexity of the online learning system and senior management support to implement online learning systems during the COVID-19 crisis

\begin{tabular}{|c|c|c|c|c|c|c|}
\hline Variables & SD & D & $\mathrm{N}$ & A & SA & Total \\
\hline Using online learning system is complicated and difficult to deal with & 5 & 36 & 28 & 18 & 3 & 90 \\
\hline $\begin{array}{l}\text { The online learning system will be difficult to integrate within the institute current learning } \\
\text { system after the end of the COVID-19 crisis. }\end{array}$ & 7 & 33 & 25 & 20 & 5 & 90 \\
\hline Online learning is well integrated with my learning system already. & 4 & 14 & 26 & 38 & 8 & 90 \\
\hline Total & 16 & 83 & 79 & 76 & 16 & \\
\hline $\begin{array}{l}\text { The institute senior management is currently investing in online learning systems during } \\
\text { COVID-19 crisis }\end{array}$ & 1 & 9 & 22 & 42 & 16 & 90 \\
\hline $\begin{array}{l}\text { The institute senior management should invest more in online learning system after the } \\
\text { end of COVID-19 crisis. }\end{array}$ & 2 & 4 & 23 & 41 & 20 & 90 \\
\hline Total & 3 & 13 & 44 & 83 & 36 & 179 \\
\hline
\end{tabular}

Table 5 shows that a total of $65 \%$ respondents either agree or strongly agree that there are advantages of online learning over the conventional learning, $21 \%$ of the respondents were neural, and just $12 \%$ of the respondents feel there isn't any advantage of using the online learning.

Table 6 is very helpful to answer all the critics of online learning claiming that online learning tools are complicated to grasp. However, the survey claims that a small proportion of the respondents believe the online systems are complex. A majority of the participants believe the other way around, a reason for that may be the excessive use of the web and social media over the years, making the people comfortable with teaching systems. 
Table 7. Collaboration techniques for work from home approach and Degree of competition

\begin{tabular}{|c|c|c|c|c|c|c|}
\hline Variables & SD & $\mathrm{D}$ & $\mathrm{N}$ & A & SA & Total \\
\hline The institute provides its collaboration systems to conduct online learning during the crisis. & 0 & 7 & 17 & 45 & 21 & 90 \\
\hline $\begin{array}{l}\text { The institute provides tools to conduct meetings and work with teams remotely to guide } \\
\text { members and complete tasks. }\end{array}$ & 0 & 3 & 11 & 47 & 29 & 90 \\
\hline $\begin{array}{l}\text { Online learning system online tools used in my institute provide methods for the } \\
\text { automation and management of tasks in the academic process. }\end{array}$ & 3 & 11 & 26 & 37 & 13 & 90 \\
\hline $\begin{array}{l}\text { The online learning system used in my institute provides tools for document management } \\
\text { that support all stages of issuance and approval of official documents. }\end{array}$ & 1 & 11 & 31 & 33 & 14 & 90 \\
\hline Total & 4 & 32 & 85 & 162 & 77 & 360 \\
\hline $\begin{array}{l}\text { The institute where I work is facing pressures from the surrounding work environment to } \\
\text { activate the online learning system, given the current conditions of the fast-spreading } \\
\text { COVID-19. }\end{array}$ & 3 & 22 & 30 & 27 & 8 & 90 \\
\hline $\begin{array}{l}\text { The institute would lose many competitive advantages in the higher education sector, if it } \\
\text { does not adopt the online learning system during the COVID-19 crisis. }\end{array}$ & 1 & 7 & 20 & 42 & 20 & 90 \\
\hline $\begin{array}{l}\text { The curriculum would not be covered by the end of the semester, if the institute does not } \\
\text { adopt the online learning system during the COVID-19 crisis. }\end{array}$ & 0 & 11 & 15 & 36 & 28 & 90 \\
\hline $\begin{array}{l}\text { The use of the online learning system is an urgent necessity, given the current conditions } \\
\text { of the fast-spreading COVID-19. }\end{array}$ & 0 & 2 & 7 & 35 & 46 & 90 \\
\hline Total & 4 & 42 & 72 & 140 & 102 & 360 \\
\hline
\end{tabular}

Table 8. Technical competence and preparedness, Density of information, and flexibility of work

\begin{tabular}{|c|c|c|c|c|c|c|}
\hline Variables & SD & $\mathrm{D}$ & $\mathrm{N}$ & A & SA & Total \\
\hline $\begin{array}{l}\text { The technology infrastructure at my institute can support online learning system } \\
\text { applications during the COVID-19 crisis. }\end{array}$ & 1 & 12 & 19 & 38 & 20 & 90 \\
\hline $\begin{array}{l}\text { The institute administration provides specialized training for instructors to be able to } \\
\text { effectively deliver their courses online during the COVID-19 crisis. }\end{array}$ & 3 & 12 & 24 & 36 & 15 & 90 \\
\hline My colleagues are quite familiar with work from home during the COVID-19 crisis. & 1 & 9 & 22 & 42 & 16 & 90 \\
\hline Total & 5 & 33 & 64 & 116 & 51 & \\
\hline The online learning system requires a lot of data, including audio, pictures and video & 0 & 5 & 10 & 53 & 22 & 90 \\
\hline The curriculum is not designed to be delivered through a online learning system. & 1 & 11 & 21 & 35 & 22 & 90 \\
\hline $\begin{array}{l}\text { The teaching process is complex, and it is difficult to merely use a online learning system to } \\
\text { accomplish it. }\end{array}$ & 5 & 14 & 23 & 33 & 15 & 90 \\
\hline \multirow[t]{2}{*}{ Total } & 6 & 30 & 54 & 121 & 59 & 270 \\
\hline & 8 & 13 & 19 & 34 & 16 & 90 \\
\hline $\begin{array}{l}\text { The online learning system during the COVID-19 crisis requires more time to complete the } \\
\text { required tasks than normal working hours }\end{array}$ & 3 & 6 & 14 & 30 & 37 & 90 \\
\hline $\begin{array}{l}\text { The online learning system during the COVID-19 crisis requires a dedicated place and a } \\
\text { suitable environment to be able to complete work duties. }\end{array}$ & 2 & 2 & 16 & 33 & 37 & 90 \\
\hline Total & 5 & 8 & 30 & 63 & 74 & \\
\hline
\end{tabular}

\section{Findings Related to Research Question/Objective Two}

In this subsection, we present the data collected on the perceptions of educators on the effectiveness of online education during COVID-19 crisis in UAE. To get the findings of objective two, the content analysis of the survey on the perception of teachers and students over online learning has been performed. In addition to informal interviews, the researchers also collected detailed information over the essentials of the online teaching-learning process. Although self-motivation can work but gradually, most educators stated that faculty can be motivated only if they can be convinced that the online methods have more advantages during the crisis. Table 7 shows that the majority of participants either strongly disagree or disagree on the collaboration techniques for work from home as well as degree of completion. This shows that this issue needs to be addressed better by academic institutions.

Table 8 shows that there was no common agreement on technical competence and preparedness, while there was tendency to agree on high density of information delivered using online methods as well as on the flexibility of work. 
Table 9. Benefits of using a remote work system and overall effectiveness of using the online learning

\begin{tabular}{|c|c|c|c|c|c|c|}
\hline Variables & SD & $\mathrm{D}$ & $\mathrm{N}$ & A & SA & Total \\
\hline $\begin{array}{l}\text { Using the online learning system during the COVID-19 crisis helps me manage the teaching } \\
\text { process effectively. }\end{array}$ & 1 & 12 & 21 & 48 & 8 & 90 \\
\hline $\begin{array}{l}\text { Using the online learning system during the COVID-19 crisis helps me increase my work } \\
\text { productivity. }\end{array}$ & 6 & 11 & 26 & 39 & 8 & 90 \\
\hline $\begin{array}{l}\text { Using the online learning system during the COVID-19 crisis helps me get the job done } \\
\text { quickly. }\end{array}$ & 8 & 23 & 23 & 30 & 6 & 90 \\
\hline $\begin{array}{l}\text { Using the online learning system during the COVID-19 crisis has improved students' } \\
\text { attendance. }\end{array}$ & 11 & 14 & 24 & 32 & 9 & 90 \\
\hline $\begin{array}{l}\text { Using the online learning system during the COVID-19 crisis has improved students' } \\
\text { participation in-class activities. }\end{array}$ & 18 & 21 & 26 & 19 & 6 & 90 \\
\hline $\begin{array}{l}\text { The use of work from home approach during the (COVID-19) crisis improves the quality of } \\
\text { the teaching process }\end{array}$ & 8 & 19 & 36 & 22 & 5 & 90 \\
\hline $\begin{array}{l}\text { The use of work from the home approach during the COVID-19 crisis increases the } \\
\text { institute's competitiveness. }\end{array}$ & 8 & 8 & 35 & 30 & 9 & 90 \\
\hline $\begin{array}{l}\text { The use of work from the home approach during the COVID-19 crisis increases my } \\
\text { confidence in delivering course content. }\end{array}$ & 4 & 11 & 31 & 30 & 14 & 90 \\
\hline $\begin{array}{l}\text { Using the online learning system during the COVID-19 crisis helps me manage the teaching } \\
\text { process effectively. }\end{array}$ & 1 & 12 & 21 & 48 & 8 & 90 \\
\hline Total & 64 & 119 & 222 & 250 & 65 & \\
\hline $\begin{array}{l}\text { The use of the online learning system during the COVID-19 crisis is effective in completing } \\
\text { work duties. }\end{array}$ & 3 & 14 & 22 & 41 & 10 & 90 \\
\hline $\begin{array}{l}\text { I will continue to use the online learning system in the future as it is effective in conducting } \\
\text { the work }\end{array}$ & 4 & 16 & 31 & 28 & 11 & 90 \\
\hline $\begin{array}{l}\text { I intend to increase my use of the online learning system in the future because it proved to } \\
\text { be effective in conducting the work }\end{array}$ & 3 & 18 & 30 & 28 & 11 & 90 \\
\hline \multirow[t]{2}{*}{ Total } & 10 & 48 & 83 & 97 & 32 & \\
\hline & 8 & 13 & 19 & 34 & 16 & 90 \\
\hline $\begin{array}{l}\text { The online learning system during the COVID-19 crisis requires more time to complete the } \\
\text { required tasks than normal working hours }\end{array}$ & 3 & 6 & 14 & 30 & 37 & 90 \\
\hline $\begin{array}{l}\text { The online learning system during the COVID-19 crisis requires a dedicated place and a } \\
\text { suitable environment to be able to complete work duties. }\end{array}$ & 2 & 2 & 16 & 33 & 37 & 90 \\
\hline Total & 5 & 8 & 30 & 63 & 74 & \\
\hline
\end{tabular}

\section{Findings Related to Research Question/Objective Three}

In this subsection, the challenges faced by the educators in adapting to the online education requirements in UAE imposed by COVID-19 crisis (e.g., limited mobility, online assessment, student behavior, etc.).

Table 9 addressed the benefits of using a remote work system and effectiveness of Distance Learning. Reponses were distributed along the spectrum, with some slight tendency to agree on the having some benefits for remote learning. This is interesting the switch to online learning came at an unexpected time, with no prior perpetration.

Table 10 provides the analysis of how COVID-19 affected various activities including: teaching and learning, Exams, and research. The results indicate that these institutes were not ready for this sudden change, or they might not have had the proper infrastructure or means to switch to the online learning system. In addition, results show the lack of readiness for such sudden unexpected conditions in terms of decision related to exams. Finally, the table shows that research activities for most participants were affected by this situation.

Table 11 shows the impact of COVID-19 on activities and abilities of participants. The first part shows that the analysis of 79 respondent representing $89.78 \%$ opted yes that there is an impact of COVID-19 on your mobility while 11 respondent representing $12.22 \%$ opted otherwise. The second part shows that most institutes, with 82 respondents, were working on plans to address exams hoping to find an alternate for the assessments. They understand that traditional assessments are not in a way helpful for online teaching. 
Table 10. How has COVID-19 affected various activities including: teaching and learning, Exams, and research?

\begin{tabular}{|c|c|c|c|c|c|c|c|}
\hline \multicolumn{3}{|l|}{ Teaching and learning } & \multicolumn{3}{|l|}{ Exams as planned } & \multicolumn{2}{|l|}{ Affected research } \\
\hline Variable & $\mathrm{F}$ & $\mathrm{P}$ & Variable & $\mathrm{F}$ & $\mathrm{P}$ & Variable & $\mathrm{F}$ \\
\hline It is not affected & 2 & $2.2 \%$ & Yes, as usual & 16 & $17.8 \%$ & $\begin{array}{l}\text { Conferences canceled or } \\
\text { postponed }\end{array}$ & 53 \\
\hline $\begin{array}{l}\text { Classrooms replaced } \\
\text { by distance teaching }\end{array}$ & 71 & $78.7 \%$ & $\begin{array}{l}\text { Yes, through new } \\
\text { measures }\end{array}$ & 63 & $70.0 \%$ & Travel has been canceled & 41 \\
\hline $\begin{array}{l}\text { Activities suspended, } \\
\text { working on solutions. }\end{array}$ & 17 & $19.1 \%$ & $\begin{array}{l}\text { Yes, in part, some } \\
\text { will be postponed }\end{array}$ & 8 & $8.9 \%$ & $\begin{array}{l}\text { Projects in danger of not being } \\
\text { completed }\end{array}$ & 26 \\
\hline \multirow[t]{3}{*}{ Canceled teaching } & 0 & $0 \%$ & $\begin{array}{l}\text { No, exams are at risk } \\
\text { of postpone }\end{array}$ & 2 & $2.2 \%$ & All research has stopped & 11 \\
\hline & & & $\begin{array}{l}\text { No, all exams are on } \\
\text { hold }\end{array}$ & 0 & $0 \%$ & & \\
\hline & & & Don't know & 1 & $1.1 \%$ & & \\
\hline Total & 90 & 100 & Total & 90 & 100 & Total & \\
\hline
\end{tabular}

Table 11. Impact of COVID-19 on activities and abilities of participants

\begin{tabular}{lccc}
\hline Metric Question & Yes & NO & Total \\
\hline Has there been an impact of COVID-19 on your mobility? & 79 & 11 & 90 \\
\hline Are strategies being discussed to address the above issue of exams? & 82 & 8 & 90 \\
\hline Is your institution involved in COVID-19 related research? & 29 & 61 & 90 \\
\hline Has COVID-19 affected research direction and efforts at your institution? & 65 & 25 & 90 \\
\hline Are you involved in community activities in the context of COVID-19? & 25 & 65 & 90 \\
\hline
\end{tabular}

Table 12. Analysis of COVID-19 impact on students' enrollment and behavior as well as responder's community engagement

\begin{tabular}{|c|c|c|c|c|c|c|c|c|}
\hline Student enrollment & & & Students' behavior & & & Community e & & \\
\hline Variable & $\mathrm{F}$ & $\mathrm{P}$ & Variable & $\mathrm{F}$ & $\mathrm{P}$ & Variable & $\mathrm{F}$ & $\mathrm{P}$ \\
\hline No & 49 & $53.4 \%$ & Often seems worried & 40 & $47.1 \%$ & Not affected & 6 & $6.7 \%$ \\
\hline Yes, only international & 9 & $10.2 \%$ & Often unhappy & 17 & $20.0 \%$ & Increased & 13 & $14.6 \%$ \\
\hline Yes, only local & 17 & 19.32 & $\begin{array}{l}\text { Nervous and easily } \\
\text { loses confidence }\end{array}$ & 8 & $9.41 \%$ & Decrease & 54 & $59.5 \%$ \\
\hline $\begin{array}{l}\text { Yes, both local and } \\
\text { international }\end{array}$ & 15 & $17.1 \%$ & Has many fears & 25 & $23.5 \%$ & Don't know & 17 & $19.1 \%$ \\
\hline Total & 90 & 100 & Total & 90 & 100 & Total & 90 & 100 \\
\hline
\end{tabular}

The third part of the table shows the analysis of 29 respondent representing 32\% opted Yes that their institution involved in COVID-19 related research, while 61 respondents opted otherwise. The following item provides the analysis of 65 respondents opted Yes that their COVID-19 affected research direction and efforts at your institution, while 25 respondents opted otherwise. A reason for that maybe that researchers don't have access to the research labs and the resources that are indispensable for them to carry out the research. The last item of the table gives the analysis of 24 respondents opted Yes that their COVID-19 affected research direction and efforts at your institution, while 65 respondents opted otherwise.

\section{Findings Related to Research Question/Objective Four}

In this subsection, the findings on how the student engagement was affected by online learning during COVID-19 crisis from educators perspective in UAE. The participants were asked problems they faced while performing online learning. The questions were specifically asked from the instructor participants, to get an overview of where they feel improvements can be made.

Table 12 shows analysis of COVID-19 impact on students' enrollment and behavior as well as responder's community engagement. The last part of Table 12 gives the analysis of impacted on community engagement. When asked, 6 respondents said that it has not affected it, 13 respondents said that it has increased our 
community engagement, 53 respondents opted that It has decreased our community engagement while 17 respondents responded Don't know.

The majority of participants believe that a lack of visual feedback and proper annotation resources as real challenges that hamper the success of online learning. 10 respondents stated that students faced difficulties in understanding the theoretical concepts. 90 agreed that students faced problems in hands-on, as the students didn't have needed machinery at their residences. 85 agreed that drawing annotations was hard. 50 agreed that ensuring the credibility of exams was hard. Finally, 75 agreed about the lack of visual feedback from students. We conclude that students felt comfortable with online education, but they also thought that it was not a replacement of visual communication with instructors as well as they faced real difficulties of hands-on experience especially for engineering labs and medical training.

\section{DISCUSSION AND RECOMMENDATIONS}

\section{Discussion of Results}

This paper studied the perception of educators in key higher education institutes in UAE on the impact, effectiveness, and challenges of online education system used during the COVID-19 lockdown period. The paper managed to evaluate the reliability and construct validity of an online education performance from educators' perspectives including transition to a student-centered online learning in a relatively short period of time. Furthermore, this paper evaluated two major sudden changes in the higher education system within the UAE, the first was the ability to perform digital transformation and the second was the transition to a sudden online learning process. In the first aspect, instructors were forced to switch to student centered approach which was shown to be very challenging for many participants.

According to Hodges et al. (2020), online learning can offer many opportunities for learners but requires deep evaluation in order to identify its impact on students' learning experience, to provide data on how online practices can be improved, and to provide an evidence that can be used in better future implementation of online education. A good proportion of the educator respondents feel that online learning is advantageous over the traditional classroom setup. A reason for this might be easy accessibility to the recorded material, and real-time demonstrations of some hard concepts using Audio Visual and other demonstration tools, which are otherwise hard to grasp. Our results corroborate with other studies conducted in this regard (Almaiah et al., 2020).

Our findings are also in line with other studies (Kundu \& Bej, 2021) where it was confirmed that online educational process resulted in less engagement from students as well as fear perception associated with the online shift. In fact, the preference was to use a hybrid approach that combines both face-to-face with online based education especially for freshman students as well as programs with hands-on components. Furthermore, the results of this study are aligned with other studies as well with respect to the necessity of online education during lockdown period (Coman et al., 2020; Malkawi et al., 2021). In addition, as other studies suggested, courses need to integrate synchronous education meetings as well asynchronous ones for better benefits (Tzivinikou et al., 2020). Another important aspect that was highlighted by this study is the ability of available resources of institutes to switch into remote learning with the support of technology and online tools, which agrees with what presented in (Lokanath et al., 2020). Finally, one of the main benefits of the situation was connecting participants to the community worldwide and having more freedom in some aspects, which was consistent with finding in (Paudel, 2021). Overall, we believe that the finding of this study was interesting, this is because it was conducted with educators' perspective under an emergent situation among the sudden transform into online education, and despite results were consistent with findings of several other studies.

Furthermore, several instructors highlighted that there are many challenges in the transformation to the online process, and that several other activities were affected, including professional ones and social ones. This could affect the whole education process and result in worse outcomes at all aspects of the profession of the instructor. Based on the educators' perceptions, the UAE's adoption for remote education was 
successful as the education system has high degree of readiness similar to some other countries like China, India, during the period of COVID-19 pandemic (Demuyakor, 2020; Muthuprasad et al., 2021). It has also been found that most universities in UAE preparedness was fitted with techno-academic blending mode of delivery. At the beginning, some technical issues were faced like connectivity and video issues but this was later backed up heavily by many governmental initiatives. In addition, most of the educators were trained by institutions with hands-on experiences to use the available online learning tools like Zoom and various LMSes. Some educators felt that it is challenging to use new instructional technology. Other online platforms were also explored like Telegram, WhatsApp, and many others to widen their academic acquaintance. Most educators confirmed that they have been dependent on uploading and downloading study material on LMS already. Technology support and Internet Connectivity is not a major issue in UAE and hence most students and educators have access to learning resources and can interact with instructors anytime. Furthermore, educators reported that students did not have problems in understanding the theoretical concepts rather doing the hands-on due to lack of the appropriate infrastructure at their homes.

Qualitative findings corroborate the findings of (Malkawi et al., 2021) where it shows that various forms of online educational resources are needed for student to effectively utilize their times during the lockdown period. In some colleges, some educators are faced with the challenge of using technology in online learning for the first time and hence they need to be backed up with support of free tools (Pappas, 2021). This is in line with perception of many educators in UAE who also encouraged the free access of online learning resources. This is also asserted by Muthuprasad et al. (2021) who stresses the need for flexible learning choices and resources to make the process of learning outcome useful and fun. This can be achieved through the adoption of a learner-centered approach.

Another important finding out the pandemic is that there is a need to sustain and utilize online education process even after the end of COVID-19. Enhancements can always be carried out based on the feedback gathered from both educators and students about the pros/cons of online learning until a desired level of student's satisfaction is achieved. Most of UAE Universities uses LMS portal and their official websites alerting students on all ongoing activities. This supports Muthuprasad et al. (2021)'s finding that some digital tools on online learning platforms shall be setup in advance to avoid future hassles in communication. Another important issue raised by the educators is related to teaching practical classes online remotely. Such process proved to be difficult as it requires methodical illustration of experiments in the presence of the students to be effective. In all cases, online mode of conducting experiments with simulations has been adopted as an emergent solution to handle the COVID-19 pandemic limitations. Currently, it is showed to be somewhat useful. More viable solutions are still needed in the future. We believe that a more detailed analysis and also a long-term evaluation of the current situation to develop a long term plan for proper alternatives to the conventional learning process as COVID-19 crisis is continuing. This can be achieved by expanding the horizons of this study by taking a lead in exploring the other unknown factors so that online teaching learning becomes an alternative to the current conventional learning process even after the end of the COVID-19 crisis. One more challenge for the teachers is maintaining the credibility of exams, and there is a consensus among the respondents that the conventional exams are not suited for online teaching, and some other way of assessing the student performance should be devised. Hence, better online assessment tools are still needed to support integrity and reliability.

A good proportion of the respondents feel that there has been a decline in the research activities in their institutions, have been plummeted with most of the conferences and seminars either canceled or postponed for the later dates. And researchers being unable to return to the laboratories is an insult to the injury. Educators also believe that courses must incorporate opportunities for synchronous (real-time) communications. Many educators also utilize social media channels for communication due to their community orientation and other useful capabilities. The educators stressed the fact that important correlation exists between faculty engagement and course success. Faculty teaching online should feel their huge impact on the course and program outcomes. In general, it is found that many levels of faculty teach online courses as they teach traditional courses at the same time. Educators feel that logistic support and technical assistance to students consumes a lot of their time and efforts. Many educators feel that higher 
education institutions provide great opportunity to design new distance education programs using costeffective approach.

\section{Recommendations}

The results of this paper showed that a paradigm shift in the implementation and adoption of online learning solutions is widely needed. In particular, the following recommendations are vital for better delivery of online learning from educators' perspectives. First, the assessment activities are a big challenge for educators when it comes to integrity and authenticity of the exam paper submitted by students. The currently used technology tools are not sufficient to support the integrity of the exams and assessment activities. As such, a more practical assessment model that fits the online learning is still required. Second, student engagement practices being followed today are not enough to encourage students to participate and interact. As such, new innovative methods of getting the students engaged are still needed. Third, institutions shall include faculty experience in online learning and technology use when hiring new educators. At the same time, existing faculty must be provided with effective training on online learning tools and instructional design methodologies and to be compensated for their training time. Further, the establishment of university level task force to help in the design, implementation, and evaluation of online learning courses and programs are needed on urgent basis. Third, many educators agree that online courses do normally increase both the course size and faculty workload issues. These have quality implications on the delivery of courses and programs hindering faculty interests. Quality instruction in larger classes can be assured only if a reduction in teaching load among other incentives are provided to faculty.

\section{STUDY LIMITATIONS}

This research provided analysis on how the educational process was impacted in UAE higher education institutions due to COVID-19 pandemic including recommendations for improvement of online teachinglearning process from educator's perspectives. However, the research also has some limitations. One limitation is represented by the assumption that all UAE universities had the same capabilities of online education (e.g., high quality learning management system) prior to the COVID-19 crisis, although universities are different in this perspective. To have precise results, we might make comparisons according to universities size, fields of study, previous experience of universities with online learning, educators' adaptation to the transition period. Another potential limitation of this research work is that most of the respondents were based in Abu Dhabi, the questionnaires were sent to the educators in other emirates as well, however, authors didn't receive any responses. Hence the sample is not representative of the whole UAE. On the other hand, we can argue that since most higher education institutions are based in Abu Dhabi and Dubai it doesn't affect the correctness of the results of this research. There is a lack of earlier research studies on this topic in UAE, hence it was difficult to evaluate the outcomes and have quantitative measurement for the effects of the sudden transform over progression time of this pandemic.

\section{CONCLUSION}

During COVID-19 pandemic lock down, the need for online learning becomes a necessity all over the world. This paper attempted to seek instructor/faculty views of the status of e-learning during COVID-19 in UAE as a case study. The focus was to find out if proper and adequate e-learning facilities and support are available from educators' perspective. Researchers have identified some of the key issues associated with the adoption of e-learning facilities during COVID-19. In general, the findings indicate that $20.82 \%$ of participants agree that online learning during COVID-19 promotes student's engagement. However, $29.49 \%$ of the participants indicated that e-learning does not promote student engagement. The main outcome of this states that educational institutes should provide regular training, in particular for new faculties to ensure that they adapt to these new measures and follow them. The study also recognizes some of the inhibiting factors affecting e-learning during the COVID-19 pandemic, such as distractions and time management; lack of student's interest and staying motivated, adapting to unfamiliar technology, understanding course expectations, and technical issues. This study also highlighted that the level engagement in the e-learning is still on average. 
Hence, institutes should accommodate the new challenges through the acquisition and installation of contemporary online education systems and provide necessary technologies to implement new policies. This would improve lecturers'/students' performance and increase the usage of the online learning tools.

Author contributions: The first and last author made the most significant contribution to this paper. All authors were involved in concept, design, collection of data, interpretation, writing, and critically revising the article. All authors approve final version of the article.

Funding: This research received no external funding.

Declaration of interest: The authors declare no conflict of interest.

Data availability: Data generated or analysed during this study are available from the authors on request.

Acknowledgements: The Ministry of Education in UAE is acknowledged for their help and support for this study. The authors thank all participating faculty of targeted institutions in UAE.

\section{REFERENCES}

Almaiah, M. A., Al-Khasawneh, A., \& Althunibat, A. (2020). Exploring the critical challenges and factors influencing the E-learning system usage during COVID-19 pandemic. Education and Information Technologies, 25(1), 5261-5280. https://doi.org/10.1007/s10639-020-10219-y

Almanthari M., A., Maulina, S., \& Bruce, S. (2020). Secondary school mathematics teachers' views on elearning implementation barriers during the COVID-19 pandemic: The case of Indonesia. EURASIA Journal of Mathematics, Science and Technology Education, 16(7), em1860. https://doi.org/10.29333/ejmste/8240

Basilaia, G., \& Kvavadze, D. (2020). Transition to online education in schools during a SARS-CoV-2 coronavirus (COVID-19) pandemic in Georgia. Pedagogical Research, 5(4), em0060. https://doi.org/10.29333/pr/7937

Baticulon, R. E., Sy, J. J., Alberto, N. R.., Baron, M. B. C., Mabulay, R. E. C., Rizada, L. G. T., \& Reyes, J. C. B. (2021). Barriers to online learning in the time of COVID-19: A national survey of medical students in the Philippines. Medical Science Educator, 1-12. https://doi.org/10.1007/s40670-021-01231-z

Coman, C., Țîru, L. G., Meseșan-Schmitz, L., Stanciu, C., \& Bularca, M. C. (2020). Online teaching and learning in higher education during the coronavirus pandemic: Students' perspective. Sustainability, 12(24), 10367. https://doi:10.3390/su122410367

Demuyakor, J. (2020). Coronavirus (COVID-19) and online learning in higher institutions of education: A survey of the perceptions of Ghanaian international students in China. Online Journal of Communication and Media Technologies, 10(3), e202018. https://doi.org/10.29333/ojcmt/8286

García-Peñalvo, F. J., Corell, A., Rivero-Ortega, R., Rodríguez-Conde, M. J., \& Rodríguez-García, N. (2021). Impact of the COVID-19 on higher education: An experience-based approach. In Information Technology Trends for a Global and Interdisciplinary Research Community (pp. 1-18). IGI Global. https://doi.org/10.4018/978-1-7998-4156-2.ch001

García-Morales, V. J., Garrido-Moreno, A., \& Martín-Rojas, R. (2021). The transformation of higher education after the COVID disruption: Emerging challenges in an online learning scenario. Frontiers in Psychology, 12, 196. https://doi.org/10.3389/fpsyg.2021.616059

Hamid, Y., Al-Karaki, J. N., Nseobot, i. R., Effiong, a. I., dinnoo, v., \& edet, a. U. (2020). A simple and predictive model for COVID-19 evolution in large scale infected countries. Journal of Theoretical and Applied Information Technology, 98(24), 3961- 3971.

Hodges, C., Moore, S., Lockee, B., Trust, T., \& Bond, A. (2020). The difference between emergency remote teaching and online learning. Educause Review, 27, 1-12. Retrieved 15 June 2020 from https://er.edu cause.edu/articles/2020/3/the-difference-between-emergency-remote-teaching-and-online-learning 
Huang, R. H., Liu, D. J., Tlili, A., Yang, J. F., Chang, T.-W., Wang, H. H., \& Zhuang, R. (2020). Handbook on facilitating flexible learning during educational disruption: The Chinese experience in maintaining undisrupted learning in COVID-19 outbreak. Beijing: Smart Learning Institute of Beijing Normal University. https://doi.org/10.1163/9789004459113

Iyer, P., Aziz, K., \& Ojcius, D. M. (2020). Impact of COVID-19 on dental education in the United States. Journal of Dental Education, 84(6), 718-722. https://doi.org/10.1002/jdd.12163

Kathleen Gray K., Chang S., \& Kennedy G. (2010). Use social web technologies by international and domestic undergraduate students: Implications for internationalising learning and teaching in Australian universities. Technology Pedagogy and Education 19(1), 31-46. https://doi.org/10.1080/14759390903579208

Kundu, A., \& Bej, T. (2021). COVID-19 response: Students' readiness for shifting classes online. Corporate Governance: The International Journal of Business in Society. Vol. ahead-of-print No. ahead-of-print. https://doi.org/10.1108/CG-09-2020-0377

Lokanath, M., Gupta, T., \& Shree, A. (2020). Online teaching-learning in higher education during lockdown period of COVID-19 pandemic. International Journal of Educational Research Open, 1(2020), 100012. https://doi.org/10.1016/j.ijedro.2020.100012

Malkawi, E., Bawaneh, A., \& Bawa'aneh, M. S. (2021). Campus off, education on: UAEU students' satisfaction and attitudes towards e-learning and virtual classes during COVID-19 pandemic. Contemporary Educational Technology Journal, 13(1), ep283. https://doi.org/10.30935/cedtech/8708

Marinoni, G., Van't Land, H., \& Jensen, T. (2020). The impact of COVID-19 on higher education around the world. IAU Global Survey Report.

Mittal, A., Mantri, A., Tandon, U., \& Dwivedi, Y. K. (2021). A unified perspective on the adoption of online teaching in higher education during the COVID-19 pandemic. Information Discovery and Delivery. Vol. ahead-of-print No. ahead-of-print. https://doi.org/10.1108/IDD-09-2020-0114

Muthuprasad, T., Aiswarya, S., Aditya, K. S., \& Jha, G. K. (2021). Students' perception and preference for online education in India during COVID-19 pandemic. Social Sciences \& Humanities Open, 3(1), 100101. https://doi.org/10.1016/j.ssaho.2020.100101

Pappas, C. (2021). Free educational technology for teachers. Retrieved 6 April 2021 from https://elearningindustry.com/321-free-tools-for-teachers-free-educational-technology

Paudel, P. (2021). Online education: Benefits, challenges and strategies during and after COVID-19 in higher education. International Journal on Studies in Education, 3(2), 70-85. https://doi.org/10.46328/ijonse.32

Sintema, E. J. (2020). Effect of COVID-19 on the performance of grade 12 students: Implications for STEM education. EURASIA Journal of Mathematics, Science and Technology Education, 16(7), em1851. https://doi.org/10.29333/ejmste/7893

Tzivinikou, S., Charitaki, G., \& Kagkara, D. (2020). Distance Education Attitudes (DEAS) during COVID-19 crisis: Factor structure, reliability and construct validity of the brief DEA scale in Greek-speaking SEND teachers. Technology, Knowledge and Learning, 1-19. https://doi.org/10.1007/s10758-020-09483-1

UAE Government Portal. (2020). Handling the COVID-19 outbreak. Retrieved August 2020 from https://u.ae/ en/information-and-services/justice-safety-and-the-law/handling-the-COVID-19-outbreak

Umoh, M. J., Nseobot, I. R., Hamid, Y., Elyassami, S., Effiong, A. I., Ette, U., \& Soomro, M. A. (2020). COVID-19 city locked down: Implications on human welfare in developing countries. International Journal of Business Education and Management Studies, 4(1), 9-14. https://ssrn.com/abstract=3578134 
Viner, R., Russell, S., Croker, H., Packer, J., Ward, J., Stansfield, C., Mytton, O., Bonell, C., \& Booy, R. (2020). School closure and management practices during coronavirus outbreaks including COVID-19: A rapid systematic review. The Lancet Child \& Adolescent Health, 4(5), 397-404. https://doi.org/10.1016/s2352-4642(20)30095-x

Zhou, L., Wu, Sh., Zhou, M., \& Li, F. (2020). 'School's out, but class' on', the largest online education in the world today: Taking China's practical exploration during the COVID-19 epidemic prevention and control as an example. Best Evidence in Chinese Education, 4(2), 501-519. https://doi.org/10.15354/bece.20.ar023

Correspondence: Amjad Gawanmeh, University of Dubai, Dubai, UAE and Concordia University, Canada.

E-mail: amjad.gawanmeh@ieee.org 